\title{
EVALUATIONS OF MAGNOLIA GRANDIFLORA SELECTIONS IN SOUTH-CENTRAL ALABAMA, U.S.
}

\author{
by J.D. Williams ${ }^{2}$, J.L. Sibley', C.H. Gilliam³ ${ }^{3}$ and G. Creech ${ }^{4}$
}

\begin{abstract}
In December 1983, 12 southern magnolia (Magnolia grandiflora L.) selections were added to a comprehensive tree evaluation project at the Piedmont Substation in Camp Hill, Alabama, U.S., in USDA Plant Hardiness Zone 7b. Growth rates were determined annually. Cultivars 'Margaret Davis' and 'Smith Fogle' along with seedling selections from a native population near Mobile, Alabama, demonstrated the greatest overall annual growth after the first 18 years of the study. Foliar characteristics were evaluated in September 2000. The seedling selections and 'Majestic Beauty' had the greatest mean leaf area, with 'Little Gem' the smallest. Cultivars 'Bracken's Brown Beauty', 'Hasse', and 'Little Gem' had the most tomentose (considered "brown" in industry) abaxial leaf surface, which is considered a highly desirable trait. In 'Majestic Beauty', seedlings, Aldridge, and 'Smith Fogle', the abaxial leaf surfaces were the most glabrous (considered "green"), generally regarded as a less desirable trait.
\end{abstract}

Key Words. Southern magnolia; cultivar trials; landscape trees; leaf color.

Southern magnolias (Magnolia grandiflora L.) are considered signature species of the southern United States (generally USDA Zones 6 through 10) (Callaway 1994; Dirr 1998), reminiscent of large antebellum homes, marking the boundary lines of historic estates. However, no long-term evaluations from replicated plots of southern magnolia selections have been reported. The benefits of long-term, replicated tree evaluations at the university level are significant. Such observations are not often feasible in commercial nurseries primarily concerned with growing and marketing the best-selling plant materials, nor are such plantings likely to occur in a replicated fashion in long-term sites such as arboreta primarily concerned with display of numerous species in limited quantities. Thus, this long-term performance study in a landscape setting using 12 southern magnolia selections was initiated.

\section{MATERIALS AND METHODS}

In December 1983, 12 southern magnolia selections were added to a comprehensive tree evaluation project initiated in 1980 (Williams et al. 1993). The study was conducted at the Piedmont Substation in Camp Hill, Alabama, U.S. in USDA Plant Hardiness Zone $7 \mathrm{~b}$ in a Cecil gravelly sandy loam soil (lat. 32 $83^{\prime} \mathrm{N}$, long. $\left.85^{\circ} 65^{\prime} \mathrm{W}\right)$. Trees were planted in a randomized complete block design with three replications of three trees each for a total of nine trees per selection. Trees were spaced $7.6 \mathrm{~m}(25 \mathrm{ft})$ apart within rows and $9.1 \mathrm{~m}(30 \mathrm{ft})$ between rows. No supplemental irrigation was applied except at planting. While trees originated from several nursery sources, all trees were container grown prior to field planting and were of similar size at installation. A complete fertilizer $13 \mathrm{~N}-5.6 \mathrm{P}-10.8 \mathrm{~K}(13-13-13)$ was applied at planting and in subsequent years in early spring at $59 \mathrm{~g}$ of nitrogen $(\mathrm{N})$ per $2.5 \mathrm{~cm}$ (1 in.) of trunk caliper measured $30 \mathrm{~cm}$ (12 in.) above ground level (one pound of $\mathrm{N}$ per inch of caliper). Weed control consisted of two applications per year of Roundup or Gramoxone for post-emergence weed control and a spring application of Surflan at $1.8 \mathrm{~kg} / \mathrm{ha}(4 \mathrm{lb} / \mathrm{ac})$ for pre-emergence weed control. Herbicides were applied as directed sprays around the tree base in a $1.2 \mathrm{~m}$ to $1.8 \mathrm{~m}$ (4 to $6 \mathrm{ft}$ ) diameter. No pruning was conducted throughout the study, although there was limited deer browse in the first year. Trees were measured for height, canopy spread (NS width + EW width/2), and caliper.

In September 2000, 20 leaves were collected arbitrarily from the southwest side of each tree from 1.8 to $2.4 \mathrm{~m} \mathrm{(6} \mathrm{to} 8 \mathrm{ft}$ ) above ground level. Leaf area was determined with a Transparent Belt Conveyer Accessory Leaf Area Meter, LI-COR Model LI-3050A (LICOR Inc., Lincoln, NE) on ten leaves from each tree. Leaves for leaf area determinations were harvested from recently matured, current year's growth five nodes behind the terminal bud.

Abaxial leaf color evaluations were conducted in September 2000 on recently matured leaves harvested three nodes behind the terminal bud with a Minolta Spectrophotometer CM-2002 (Minolta Camera Co., Ramsey, NJ), which assesses color in a nonsubjective 
manner based on known coordinates in a defined color space (Voss and Hale 1998). Means were derived from ten leaves per tree with three observations (subsamples) per leaf, for a total of 30 observations per tree.

The Minolta CM-2002 separates color using the attributes of hue, value (lightness or reflectance of a surface), and chroma (purity or departure from gray). Hue can be understood by visualizing a peeled grapefruit (Voss and Hale 1998) where each segment represents a particular hue with 0 to 10 values moving left to right around a central axis. Using this method, a hue value of YR (yellow-red) 10.0 has less red and more yellow than YR 1.0. Likewise, YR 1.0 is actually closer to a red hue than a yellow hue, and YR 10.0 is closer to yellow than Y (yellow) 10.0 [which is beginning to move to the GY (green-yellow) designation]. For the purpose of data analysis, hue values were transformed into a continuous number line, analyzed, then regrouped to the appropriate hue designation. Output for the variables of value and chroma was not segmented and ranged from 0 to 10; therefore, these data required no transformation for analysis or interpretation.

All data were subjected to analysis of variance using SAS Version 6.03 (SAS 1988). Mean separations were conducted with Duncan's multiple range test at the $P=0.05$ level of significance.

\section{RESULTS AND DISCUSSION}

In general, the seedling selections from a native population near Mobile, Alabama, and 'Margaret Davis' demonstrated the greatest overall growth based on total height, caliper, and canopy width, with height and canopy width on 'Smith Fogle' being similar to 'Margaret Davis' (Table 1). Aldridge, 'Little Gem', and 'Majestic Beauty' had the least overall height growth. 'Hasse', with a canopy width of $4.4 \mathrm{~m}$ (14.2 ft) and 'Little Gem', with a canopy width of $5.2 \mathrm{~m}(17.0 \mathrm{ft})$, have the narrowest form, which is a trait expected when these cultivars are placed in landscape settings. 'Hasse', Aldridge, 'Little Gem', and 'Majestic Beauty' had the smallest caliper.

Overall, the Magnolia grandiflora seedlings were among the most vigorous growers but exhibited high tree-totree variability in crown form, leaf morphology, and canopy density-not unexpected from an unselected seedling population (Dirr 1988). Only one seedling in our study was judged to have ornamental qualities sufficient for possible introduction as a cultivar. The Aldridge cultivar is a seedling strain (from Aldridge Nursery) maintained by Von Ormy Growers, Inc. (Von Ormy, TX). Aldridge was selected over a number of years by the late R.C. Aldridge for precocity, with first blooms at 12 to 18 months. There was little variability in phenotype of the Aldridge trees, and they began blooming in the second year of the study. We have also observed an extended blooming season with the Aldridge strain, with bloom extending through the end of July. However the foliage has consistently been among the lightest green of all selections, and leaf drop during stress has been common.

Brief descriptions for many of the selections included in these trials have been listed elsewhere (Callaway 1994; Dirr 1998). Three unnamed, clonal selections (SG\#4, SG\#5, and SG\#6) were included from Shady Grove Plantation in Orangeburg, South Carolina. SG\#5 has since been released as cultivar 'Smith Fogle'. 'Smith Fogle' has an attractive ovate-pyramidal form with dark green leaves that are larger than SG\#4 and SG\#6 (Table 2). Leaf drop, a common concern among magnolia selections, has been similar to other cultivars (data not shown). SG\#4 has been dropped from production by Shady Grove, and SG\#6 is still in production at Shady Grove but at this point has not been registered as a cultivar.

Table 1. Comparison of growth of Magnolia grandiflora selections in south-central Alabama.

\begin{tabular}{llll}
\hline Selection $^{z}$ & Height $^{\mathrm{y}}$ & Caliper $^{\mathrm{x}}$ & Canopy width $^{\mathrm{w}}$ \\
\hline Aldridge & $7.41 \mathrm{~g}$ & $24.0 \mathrm{efg}$ & $6.61 \mathrm{~d}$ \\
'Bracken's Brown Beauty' & $8.74 \mathrm{de}$ & $25.4 \mathrm{def}$ & $6.76 \mathrm{~d}$ \\
'Claudia Wannamaker' & $9.22 \mathrm{bcd}$ & $27.7 \mathrm{cde}$ & $7.45 \mathrm{bcd}$ \\
'Glen St. Mary' & $8.30 \mathrm{ef}$ & $25.7 \mathrm{def}$ & $7.18 \mathrm{~cd}$ \\
'Hasse' & $8.88 \mathrm{cde}$ & $20.2 \mathrm{~g}$ & $4.35 \mathrm{e}$ \\
'Little Gem' & $7.74 \mathrm{fg}$ & $22.9 \mathrm{fg}$ & $5.17 \mathrm{e}$ \\
'Majestic Beauty' & $7.87 \mathrm{fg}$ & $20.9 \mathrm{~g}$ & $6.61 \mathrm{~d}$ \\
'Margaret Davis' & $10.05 \mathrm{~b}$ & $34.4 \mathrm{a}$ & $8.95 \mathrm{a}$ \\
Seedling & $10.88 \mathrm{a}$ & $31.9 \mathrm{ab}$ & $8.46 \mathrm{a}$ \\
Shady Grove \#4 & $9.65 \mathrm{bc}$ & $27.6 \mathrm{cde}$ & $7.16 \mathrm{~cd}$ \\
Shady Grove \#6 & $8.91 \mathrm{cde}$ & $28.8 \mathrm{bcd}$ & $8.03 \mathrm{abc}$ \\
'Smith Fogle' (SG\#5) & $9.68 \mathrm{bc}$ & $29.9 \mathrm{bc}$ & $8.37 \mathrm{ab}$ \\
\hline
\end{tabular}

${ }^{2}$ Selections included Aldridge, a seedling strain from Von Ormy, Texas; a group of seedlings from a native population near Mobile, Alabama; numbered selections from Shady Grove Plantation, South Carolina; and eight recognized cultivars from various nursery sources. Means separated by Duncan's multiple range test $(P=0.05)$ are not considered different if followed by the same letters.

'Final height in meters following 18 years of growth (December 1983 through December 2001).

xFinal caliper measurements in $\mathrm{cm}$ taken at $30.5 \mathrm{~cm}$ (12 in.) above soil line following 18 years of growth (December 1983 through December 2001).

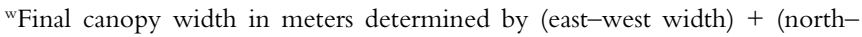
south width) $/ 2$. 
Table 2. Foliage characteristics of Magnolia grandiflora selections in south-central Alabama.

\begin{tabular}{lllll}
\hline Selection $^{z}$ & Leaf area & Hue $^{\mathrm{x}}$ & Value & Chroma \\
\hline Aldridge & $108.1 \mathrm{~b}$ & Y 1.0 ab & $5.4 \mathrm{~b}$ & $3.0 \mathrm{~d}$ \\
'Bracken's Brown Beauty' & $81.1 \mathrm{c}$ & YR 7.6 d & $5.0 \mathrm{f}$ & $2.9 \mathrm{de}$ \\
'Claudia Wannamaker' & $56.4 \mathrm{~d}$ & Y 0.1 bc & $5.6 \mathrm{a}$ & $2.9 \mathrm{de}$ \\
'Glen St. Mary' & $103.8 \mathrm{~b}$ & Y 0.1 bc & $5.3 \mathrm{~cd}$ & $3.0 \mathrm{~d}$ \\
'Hasse' & $65.6 \mathrm{~cd}$ & YR 7.8 d & $5.4 \mathrm{~b}$ & $3.3 \mathrm{bc}$ \\
'Little Gem' & $36.9 \mathrm{e}$ & YR 7.1 d & $5.4 \mathrm{bc}$ & $3.7 \mathrm{a}$ \\
'Majestic Beauty' & $139.2 \mathrm{a}$ & Y 2.7 a & $5.7 \mathrm{a}$ & $2.6 \mathrm{f}$ \\
'Margaret Davis' & $62.6 \mathrm{~cd}$ & YR 8.4 cd & $5.6 \mathrm{a}$ & $3.4 \mathrm{~b}$ \\
Seedling & $132.1 \mathrm{a}$ & Y 1.0 ab & $5.2 \mathrm{e}$ & $2.7 \mathrm{ef}$ \\
Shady Grove \#4 & $62.2 \mathrm{~cd}$ & YR 9.7 bc & $5.6 \mathrm{a}$ & $3.0 \mathrm{~d}$ \\
Shady Grove \#6 & $71.5 \mathrm{~cd}$ & YR 9.8 bc & $5.6 \mathrm{a}$ & $3.0 \mathrm{~cd}$ \\
'Smith Fogle' (SG\#5) & $112.8 \mathrm{~b}$ & Y 0.9 ab & $5.2 \mathrm{de}$ & $2.6 \mathrm{f}$ \\
\hline
\end{tabular}

${ }^{2}$ Selections included Aldridge, a seedling strain from Von Ormy, Texas; a group of seedlings from a native population near Mobile, Alabama; numbered selections from Shady Grove Plantation, South Carolina; and eight recognized cultivars from various nursery sources. Means separated by Duncan's multiple range test $(P=0.05)$ are not considered different if followed by the same letters.

'Leaf area determinations $\left(\mathrm{cm}^{2}\right)$ based on average values for ten leaves per tree with three trees per cultivar in each of three replications.

xAbaxial leaf color determined with a Minolta Spectrophotometer CM-2002 (Minolta Camera Co., Ramsey, NJ) based on average values for ten leaves per tree with three trees per cultivar in each of three replications. Color codes are Munsell where $\mathrm{Y}=$ yellow and $\mathrm{YR}=$ yellow-red.

One of the most attractive trees in the study is 'Hasse' with a narrow upright form, small leaves with dense tomentose brown backs (Table 2), and unusually good leaf retention throughout the year. 'Little Gem' also has good leaf retention and small, deep green leaves with dark brown backs. While height through 2001 has reached around $7.7 \mathrm{~m}(25 \mathrm{ft})$ for this dwarf selection, 'Little Gem' has a compact, shrublike form with multiple leaders as if having been toppruned. 'Little Gem' has the longest blooming season of all trees in our study, with heavy spring bloom followed by sporadic blooms from May through fall.

Based on our observations, 'Glen St. Mary' and 'Bracken's Brown Beauty' are worthy of the popular acclaim and widespread use they enjoy in the landscape industry. The leaves of 'Glen St. Mary' are large, and although light-brown on the underside, they tend to hang in a downward position revealing veins more evident on the upper leaf surface than most other cultivars (Table 2). The canopy has a broad pyramidal form with dense foliage, making it a good choice for landscapes needing a large magnolia. 'Bracken's Brown Beauty' is truly beautiful with the dark green leaves displayed upright exposing the velvet brown undersides. The canopy is dense, symmetrical, some- what upright and ovate, easily being one of the better choices for large spaces.

'Claudia Wannamaker' has an attractive form well suited for large spaces, with a medium growth rate compared to other cultivars in this study (Table 1). The foliage is attractive, but the leaf undersides are dusty green to light brown. 'Margaret Davis' has a broad, open canopy and is a cultivar that could also be used where a largegrowing magnolia is needed. The leaves are somewhat attractive, with brown undersides (Table 2).

Perhaps the least attractive cultivar in this study is 'Majestic Beauty', the leaves of which are the largest of any in the study, but which are also the lightest green of all but the Aldridge strain. Also, the growth habit overall is irregular, lacking any particular characteristic form, and the often redeeming value of many cultivars-a brown back to the foliage-is lacking, with undersides pale green (Table 2).

Use of color charts in plant descriptions have long been an accepted practice. However, substantial differences can exist between color charts due to the type of chart, the paper stock used for the color chips, and improper storage (Voss and Hale 1998). Furthermore, while standardizing some aspects of color, even with careful attention to the thousands of possible hue, value, and chroma combinations that can be derived from color charts, perception of color is still subject to variation by the person collecting the data.

While analysis of hues with the Minolta CM-2002 proved valuable, color separation using the attributes of value and chroma were of less direct benefit as a means of ranking the selections in this study in any particular order (Table 2). There was no distinct relationship between the attribute of value and chroma or hue. The reflectance (value) of some leaves with glabrous undersides (greenbacks) were the same as the values for some selections with heavily tomentose undersides (brownbacks) (Table 2). However, mean separations for chroma largely tracked the attributes of hue. For example, selections with the darkest brown leaf undersides also had the highest values for chroma.

These trees have developed into excellent specimens in spite of being grown under low-maintenance conditions. Furthermore, environmental conditions change such that long-term field observations are particularly valuable as a reference point for landscape 
use as opposed to the often rapid and somewhat artificial growth responses available from short-term container studies. The Auburn University Shade Tree Study site continues to be maintained for grower observations, seed collection, and tours.

\section{LITERATURE CITED}

Callaway, D.J. 1994. The World of Magnolias. Timber Press, Portland, OR.

Dirr, M.A. 1998. Manual of Woody Landscape Plants (5th ed.) Stipes Publishing, Champaign, IL, pp. 122-125.

SAS Institute Inc., 1988. SAS/STAT User's Guide. Release 6.03 Edition. SAS Institute Inc. 1,028 pp. Cary, NC.

Voss, D.H., and W.N. Hale. 1998. A comparison of the three editions of the Royal Horticultural Society Colour Chart. HortScience 33:13-17.

Williams, J.D., D.C. Fare, C.H. Gilliam, G.J. Keever, H.G. Ponder, and J.T. Owen. 1993. Shade Trees for the Southeastern United States. Alabama Agricultural Experiment Station, Auburn, AL.
${ }^{1 *}$ Associate Professor

${ }^{2}$ Associate Professor

${ }^{3}$ Professor

${ }^{4}$ Research Associate

Department of Horticulture

101 Funchess Hall

Auburn University, AL 36849, U.S.

${ }^{*}$ Corresponding author. 
Résumé. En décembre 1983, 12 sélections de magnolias à grandes fleurs (Magnolia grandiflora L.) ont été incorporés dans une vaste étude d'évaluation des arbres à la sous-station de Piedmont à Camp Hill en Alabama, soit en zone de rusticité 7b (zones de rusticité du USDA). Les taux de croissance ont été mesurés annuellement. Les cultivars 'Margaret Davis' et 'Smith Fogle', tout comme les sélections de semis prélevées à partir de sujets indigènes près de Mobile en Alabama, ont produit les meilleurs taux de croissance annuelle pour les 18 premières années de la recherche. Les caractéristiques foliaires ont été évaluées en septembre 2000. Les semis sélectionnés ainsi que le cultivar 'Majestic Beauty' avaient la plus grande surface foliaire moyenne, et 'Little Gem' la plus faible. Les cultivars 'Bracken's Brown Beauty', 'Hasse' et 'Little Gem' étaient ceux qui avaient le plus de duvet sur la face inférieure de leurs feuilles, ce qui est considéré comme une caractéristique très désirable. Les semis ainsi que les cultivars 'Majestic Beauty', 'Aldridge' et 'Smith Fogle' avaient la surface foliaire abaxiale la plus glabre, ce qui est considéré comme une caractéristique moins désirable.

Zusammenfassung. Im Dezember 1983 wurden 12 Magnolien-Selektionen (Magnolia grandiflora) in ein umfangreiches Baumbewertungsprojekt in der Piedmont Substation in Camp Hill, AL, in der USDA Pflanzentestbereich Zone $7 \mathrm{~b}$ eingefuigt. Die Wachstumsraten wurden jährlich bestimmt. Die Selektionen „Margaret Davis“ und „Smith Fogle“ zeigten zusammen mit einer Selektion von Sämlingen aus einer natürlich vorkommenden Population den größten jährlichen Zuwachs nach den ersten 18 Jahren dieser Studie. Die Blattcharakteristika wurden im September 2000 bewertet. Die Sämlingsselektionen und „Majestic Beauty“ hatten die größte durchschnittliche Blattfläche und „Little Gem“ die kleinste. Die Kultivare „Bracken’s Brown Beauty“, „Hasse“ und „Little Gem“ hatten die größte behaarte Blattoberfläche, was als sehr wünschenswert gilt. In „Majestic Beauty“-Sämlingen, Aldridge und „Smith Fogle" war die abaxiale Blattfläche besonders glatt, was allgemein als weniger interessante Linie geachtet wird.

Resumen. En diciembre de 1983 se seleccionaron $12 \mathrm{mag}-$ nolias (Magnolia grandiflora L.) con el fin de evaluar el proyecto de Camp Hill, AL en la Zona 7b de la USDA para plantas resistentes. Las tasas de crecimiento fueron determinadas anualmente. Los cultivares 'Margaret Davis' y 'Smith Fogle', junto con brinzales de una población nativa cerca de Mobile, AL, mostraron mayor crecimiento anual después de los primeros 18 años del estudio. Las características foliares fueron evaluadas en Septiembre del 2000. Los brinzales seleccionados y 'Majestic Beauty' tuvieron la mayor área foliar media, y 'Little Gem' la menor. Los cultivares 'Bracken's Brown Beauty', 'Hasse', y 'Little Gem' tuvieron superficie foliar tomentosa (considerada "cafe" en la industria) lo cual es contemplado como una característica altamente deseable. En 'Majestic Beauty', los brinzales, Aldridge, y 'Smith Fogle', las superficies foliares fueron glabras (consideradas "verdes") generalmente las características menos 